\title{
Pourfour du Petit Syndrome in a Patient with Thyroid Carcinoma
}

\author{
Sergi Martinez-Ramirez Carles Roig Joan Martí-Fàbregas
}

Neurology Department, Hospital de la Santa Creu i Sant Pau, Barcelona, Spain

\section{Key Words}

Horner syndrome $\cdot$ Oculosympathetic syndrome $\cdot$ Thyroid neoplasms

\begin{abstract}
The clinical presentation of Pourfour du Petit syndrome (PdPs) is the opposite of Horner syndrome. Although all disorders underlying Horner syndrome may potentially present as PdPs, very few cases of the latter have been described in the literature. We report a patient with PdPs due to carotid compression by a thyroid tumor.
\end{abstract}

\section{Case Report}

A 63-year-old man presented with episodes of right facial sweating and right blurred vision. Examination revealed reactive mydriasis, upper lid retraction and hemifacial hyperhidrosis on the right side (fig. 1a, b). Pupillary response to $10 \%$ cocaine was symmetric. A right Pourfour du Petit syndrome (PdPs) was diagnosed. The rest of the neurological examination was normal and a cranial CT did not identify any abnormalities (image not shown). Due to a previous diagnosis of a recurrent thyroid papillary carcinoma, a cervical CT was performed. The CT showed a well-defined contrast-enhanced node, which compressed and displaced the right common carotid artery (fig. 2). Cytologic study of an adenopathy in the supraclavicular region was positive for carcinoma. The otorhinolaryngology team ruled out surgery. Despite the expansive nature of the tumor lesion, a Claude-Bernard-Horner syndrome (CBHs) had not developed at the 3 -months follow-up.

\section{Discussion}

PdPs is a rare disorder characterized by mydriasis, eyelid retraction and hyperhidrosis. Owing to its clinical features, PdPs is also known as reverse Horner syndrome. Our case report provides a typical clinical picture of PdPs, while it establishes a previously unreported relationship with a recurrent thyroid tumor.

Since the first description of PdPs in the 18th century, it is thought that irritative stimuli of the sympathetic fibers (either at the cervical spine cord, first dorsal root or laterocervical level) are responsible for this focal dysautonomic syndrome. However, pathogenesis is far from being fully elucidated. First, the relationship between injury 
degree and clinical findings is contradictory. It could be expected that a slight injury of the sympathetic pathways mainly translates into axons irritation leading to PdPs, as in our patient. However, CBHs, which implies a loss of sympathetic function, is commonly associated with conditions that slightly harm the nerve fibers, e.g. carotid dissection. On the other hand, François Pourfour du Petit (1664-1741) experimentally induced sympathetic hyperactivity in dogs by cutting their cervical chains bilaterally [1]. Finally, some compressive lesions (mainly tumors) have been associated with both PdPs and $\mathrm{CBHs}$. It therefore seems that no specific causative lesions, as well as harm intensity based on a threshold, could anticipate the subsequent clinical pattern ('irritative' or 'deficitary').

Although all disorders underlying CBHs may potentially present as a PdPs, very few cases of the latter have been described in the literature. PdPs has been reported in association with intracranial aneurysms [2], non-penetrating injuries of the cervical sympathetic chain and brachial plexus [3], post-traumatic syringomyelia [4], severe cranioencephalic trauma [5], aortic malformation [6], thoracic tumors (first rib condrosarcoma [7], esophagus carcinoma [8] and lung carcinoma [9]), and maxillofacial surgery (parotidectomy [10], mandible tumor resection [11]). Regional anesthetic procedures are also a common cause of sympathetic dysfunction, including PdPs [12, 13]. In these cases, symptoms are often transient [14] and may be underdiagnosed.

PdPs outcome is highly variable. According to previously published cases, physical signs may persist for an indefinite time $[6,10,12]$ or may resolve in a few months once the underlying stimulus has stopped $[3,5,7,11]$. Interestingly, reported PdPs cases have never turned into CBHs spontaneously. Our patient had not developed a CBHs 3 months after the initial evaluation in spite of a persistent, and probably growing, sympathetic injury. Thyroid papillary carcinoma typically shows a slow progression, and we speculate that $\mathrm{CBH}$ s could have been identified if longer follow-up had been performed. Anyway, there is no current confirmation of any case showing a continuum between $\mathrm{PdP}$ and $\mathrm{CBH}$ syndromes.

To sum up, PdPs seems to be a very particular expression of a cervical sympathetic injury. Cases are few and heterogeneous, so general statements cannot be established regarding physiopathology and prognosis. However, PdPs needs to be recognized by physicians since it has the same topographic and diagnostic value as $\mathrm{CBHs}$. 


\begin{tabular}{l|l|l|l} 
Case Reports in & $\begin{array}{l}\text { Case Rep Neurol 2010;2:96-100 } \\
\text { Dol: } 10.1159 / 000319587\end{array}$ & Published online: July 28, 2010 & $\begin{array}{l}\text { ○ 2010 S. Karger AG, Basel } \\
\text { ISSN 1662-680X } \\
\text { www.karger.com/crn }\end{array}$ \\
\hline
\end{tabular}

Fig. 1. Right mydriasis, lid retraction and hyperhidrosis (a). Detail of right frontal hyperhidrosis (b).
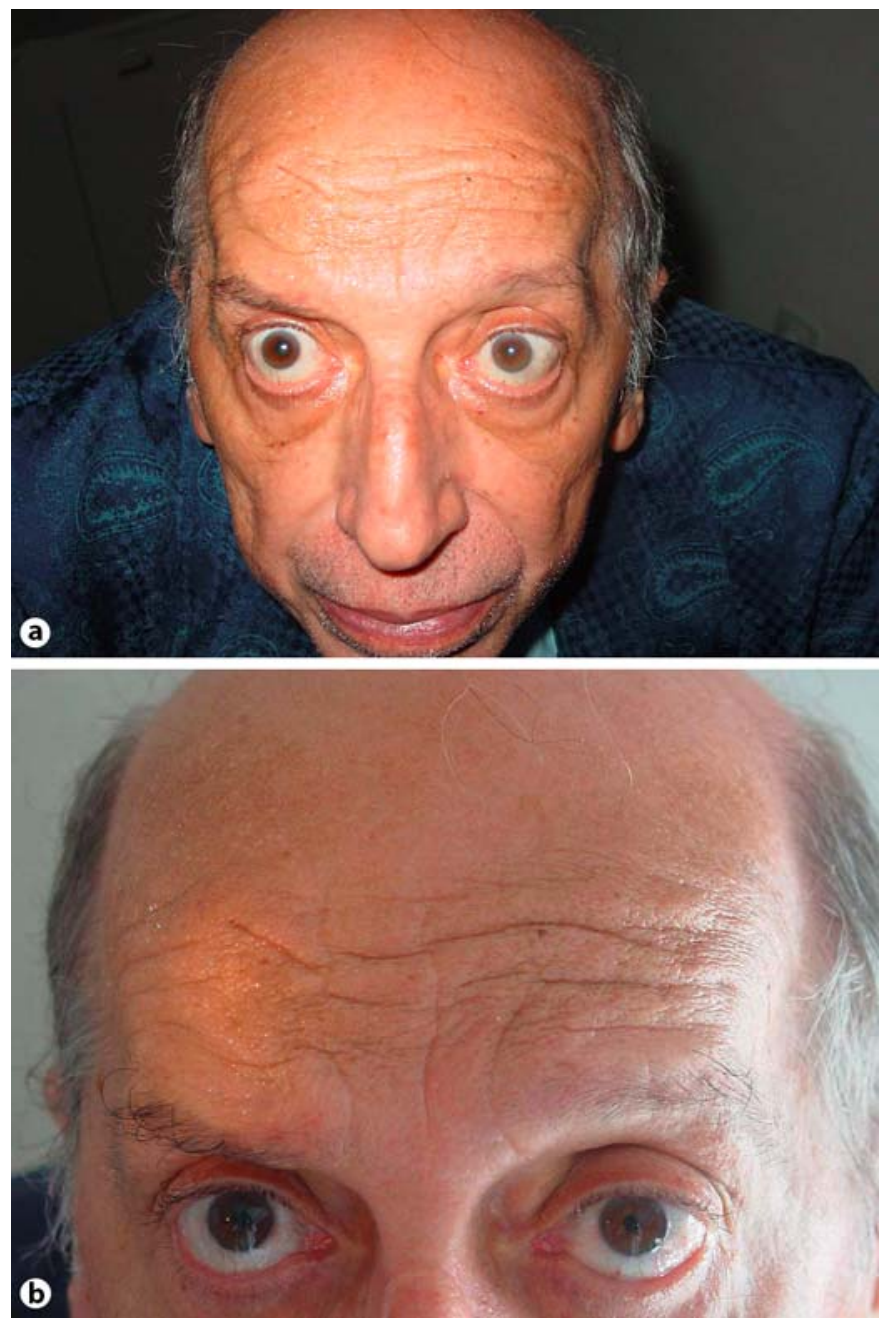


\begin{tabular}{l|l|l|l} 
Case Reports in & $\begin{array}{l}\text { Case Rep Neurol 2010;2:96-100 } \\
\text { Dol: } 10.1159 / 000319587\end{array}$ & Published online: July 28, 2010 & $\begin{array}{l}\text { ○ 2010 S. Karger AG, Basel } \\
\text { ISSN 1662-680X } \\
\text { www.karger.com/crn }\end{array}$ \\
\hline
\end{tabular}

Fig. 2. Cervical CT. Enhanced-contrast node in the right middle cervical region, suggestive of metastatic adenopathy $\left({ }^{*}\right)$. The common carotid artery is displaced medially and posteriorly (arrow).

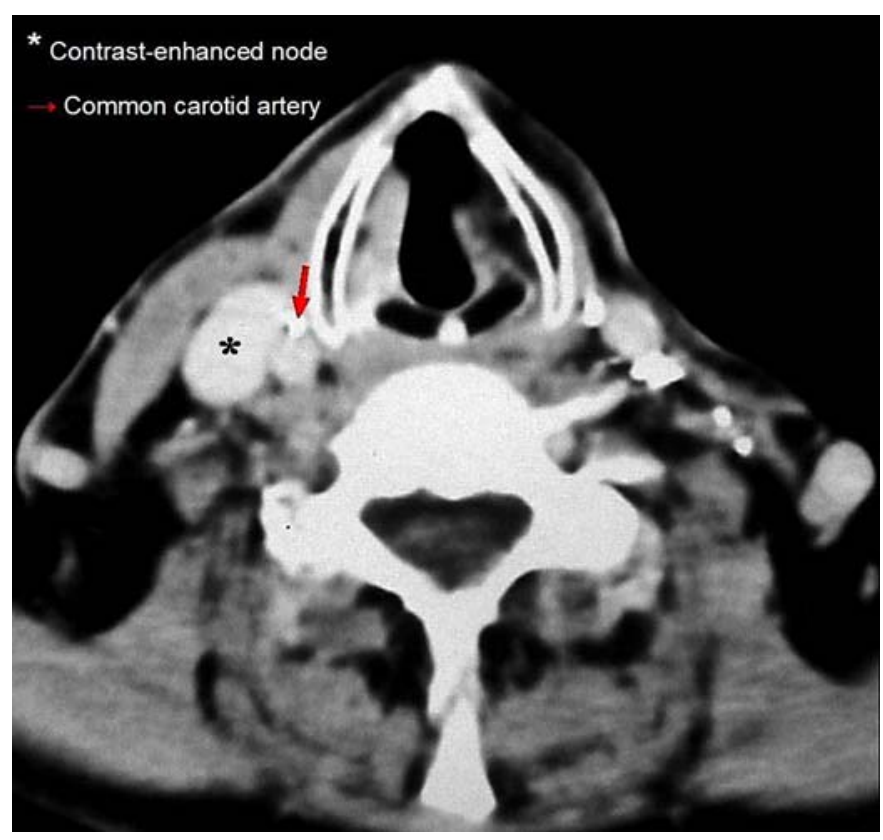




\begin{tabular}{l|l|l|l} 
Cose Reports in & $\begin{array}{l}\text { Case Rep Neurol 2010;2:96-100 } \\
\text { D01: 10.1159/000319587 }\end{array}$ & Published online: July 28, 2010 & $\begin{array}{l}\text { ○ 2010 S. Karger AG, Basel } \\
\text { ISSN 1662-680X } \\
\text { www.karger.com/crn }\end{array}$ \\
\hline
\end{tabular}

\section{References}

1 Best AE: Pourfour du Petit's experiments on the origin of the sympathetic nerve. Medical History 1969;13:154-174.

2 Nappi G, Poloni M, Bono G, Mazzella G, Bo P: Pourfour du Petit syndrome and intracranial aneurysms (author's transl). Riv Patol Nerv Ment 1976;96:354-362.

-3 Teeple E, Ferrer EB, Ghia JN, Pallares V: Pourfour Du Petit syndrome hypersympathetic dysfunctional state following a direct non-penetrating injury to the cervical sympathetic chain and brachial plexus. Anesthesiology 1981;55:591592.

-4 Kline LB, McCluer SM, Bonikowski FP: Oculosympathetic spasm with cervical spinal cord injury. Arch Neurol 1984;41:61-64.

5 Avellanal M, Fernández-Quero L, Barrios JM, Sánchez P, Navia J: Pourfour du Petit syndrome: a case following a traffic accident with severe cranioencephalic trauma. Intensive Care Med 1996;22:1090-1092.

6 Serra J, Soulen R, Moore R, McNicholas K: Interrupted aortic arch associated with Pourfour du Petit syndrome. Thorax 1986;41:217-218.

-7 Díaz Espejo CE, Boto de los Bueis A, López Domínguez JM, Blanco Ollero A, Robledo Strauss A, Casado Chocán JL: Pourfour du Petit syndrome. Neurologia 1998;13:145-147.

-8 Aouba A, Der Agopian P, Genty-Le Goff I, Mutschler C, Janin N, Patri B: Pourfour du Petit syndrome: a rare aetiology of unilateral exophtalmos with mydriasis and lid retraction. Rev Med Interne 2003;24:261-265.

9 Cole M, Berghuis J: The reverse Horner syndrome. J Thorac Cardiovasc Surg 1970;59:603-606.

10 Byrne P, Clough C: A case of Pourfour Du Petit syndrome following parotidectomy. J Neurol Neurosurg Psychiatry 1990;53:1014.

11 Mattes D, Mayer M, Feichtinger M, Lindner S: Neurological picture. A case of Pourfour du Petit syndrome following tumour surgery of the mandible. J Neurol Neurosurg Psychiatry 2009;80:69.

12 Large M, Salles C, Descoins PF, Daniaud MD, Dalbon F, Coste G: Pourfour Du Petit syndrome following brachial plexus block. Ann Fr Anesth Reanim 1984;3:232-234.

13 Forestner JE: Ipsilateral mydriasis following carotid-artery puncture during attempted cannulation of the internal jugular vein. Anesthesiology 1980;52:438439.

14 Aron J, Chatterjee D: Transient Pourfour du Petit syndrome. Anesth Analg 2007;104:1616. 